WSRC-RP-92-1397

Rev 0

December 1992

\title{
Preliminary Site Selection Report for the New Sanitary Landfill at the Savannah River Site $(U)$
}

Prepared by Savannah River Technology Center-Environmental Sciences Section

Prepared for the U.S. Department of Energy under contract no. DE-AC09-89SR18035 


\section{Preliminary Site Selection Report for the New Sanitary Landfill at the Savannah River Site}

Prepared by SRTC-ESS

\section{Executive Summary}

The Savannah River Site (SRS) has proposed a new sanitary landfill (NSL) for solid waste. A site selection team, comprised of representatives from Westinghouse Savan. nah River Company (WSRC) evaluated potential landfill sites.

The site selection team conducted an initial screening of SRS to eliminate unsuitable areas. The screening was based on criteria that were principally environmental factors; however, the criteria also included avoiding areas with unacceptable features for construction or opcration of the facility. This initial screening identified seven candidate sites for further evaluation.

Experts evaluated and rated the seven candidate sites for geological, hydrogeological, surface hydrological, ecological, and engineering criteria. The team weighted the criteria based on their relative importance in determining the site's suitability. Hydrogeology was weighted the most because of the regulatory importance attached to hydrogeological characteristics of a landfill site.

The tcarn identified four potential sites (Sites 2, 3, 4, and 5) (Figure 1) and recommends that two of the four sites (Sites 3 and 5) should receive further subsurface characterization. The two potential sites will be characterized in parallel so that flaws encountered at either site will not add valuable time to the project by starting a second subsurface characterization.

\section{Regulatory Concerns in Identifying a Landfill Site}

Since the federal regulations (October 9, 1991, 40 CFR Parts 257 and 258) for siting a solid-waste landfill do not spccify a proposed site's hydrogeologic characteristics, South Carolina Department of Health and Environmental Control (SCDHEC) provided additional regulatory guidance. However, the guidance document (Muthig 1990) will be superseded by landfill siting regulations that will be finalized in early 1993.

To efficiently site a proposed solid-waste landfill within SRS, SCDHEC will need to finalize their regulatory expectations. SCDHEC solid waste landfill siting criteria are being expedited through correspondence with $\mathrm{Mr}$. Jim Bowman. A final clarification by SCDHEC was received November 23, 1992. A landfill site selection can be confirmed when SCDHEC regulations are finalized.

\section{Methodology Employed}

Site selection is essentially a decision process that must incorporate objectives and considerations applicable to a specific project or facility. The procedure described in the following sections provides a technically-sound determination of differences and similarities among potential sites and a justification for their numeric scoring. The information presented in this report is considered to be a screening-level analysis using existing data and best professional judgement of knowledgeable subject experts. This process identifies a smaller number of candidate sites for the more detailed environmental and engineering evaluations nccessary to support National Environmental Protcction Act requirements.

\section{Site Selection Team}

A site selection task team was formed to ensure that relevant considerations and interests were considered in the selection and evaluation of candidate sites. The sitc sclection team consisted of the following represcntatives:
J. B. Gladden
WSRC, ESS
R. K. Aadland
WSRC, ESS
L. D. Wike
WSRC, ESS
H. E. Mackey, Jr.
W. L. Specht
WSRC, ESS
J. S. Haselow
WSRC, ESS
V. A. Rogers
WSRC, ESS
G. E. Taylor
WSRC, WME 

D. D. Smith
WSRC, WME
G. D. Shartzer
WSRC, WME

The site selection team identified categories and criteria for site selection and evaluation and gathered rclevant information to support the analysis. Additional technical support was sought as necessary for evaluation of specific topics. The following subject experts provided additional technical support:
J. B. McConathy
WSRC, EPD
T. G. Jordan
WSRC, EPD
M. E. Fogarty
WSRC, EPD
F. A. Brooks
SRFS
R. Roecher
SRFS

\section{Identification of Potential Sites}

The team conducted an initial screening of SRS for potential locations suitable for the NSL by identifying and applying exclusion criteria. Exclusion criteria were defined as conditions that would result in unacceptable impacts to high-quality environmental resources or would provide unacceptable features for construction or operation of the facility. The original site [Site B (WSRC 1991)] located on a plateau between Tinker Creek, Mill Creek, and $\mathrm{McQueen}$ Branch was not reevaluated because it was not in an area possessing an upward hydraulic gradient, an exclusion criterion defined in the following section.

\section{Exclusion Criteria}

Specific exclusion criteria were identified and delineated on the SRS site map where possib'e (Figure 1). By consensus, the team identified seven areas suitable for the NSL shown in Figure 1. These sites were then subjected to comparative evaluation using the screening criteria. The following subsections describe the exclusion criteria.

\section{Threatened and Endangered Species}

SRS contains populations of many species listed by federal agencies as threatened, endangered, or of special concern. Areas specifically excluded were those managed for bald eagle nesting areas, red-cockaded woodpecker colony management areas, and areas known to have rare plants. Other threatened and endangered species were considered only if potential disturbance would extend into their habitats. For example, the shortnose sturgeon was not directly considered because upland development would not have direct impact on its habitat in the Savannah River.

\section{Category 1 Wetlands and Unavoidable} Impacts to Category 1 Streams

Category 1 resources are defined as unique and irreplaceable on a national basis or in the ecoregion section (DOl 1981). At SRS this definition would include many Carolina bays and cypress-tupelo swamps. Any sitc arcas containing high-quality wetlands or headwater streams that would receive direct and unavoidable impacts as a result of the construction or operation of the NSL were also excluded from consideration. These areas included much of the headwaters drainage of Upper Threc Runs Crcek and the majority of Carolina bays.

\section{National Environmental Research Park Sites}

SRS was the first designated National Environmental Research Park (NERP). There are numerous areas around the SRS set aside for ecological and environmental research and preservation (Hillestad and Bennctt 1982). These set-aside areas and areas close enough to be dctrimental to them were excluded from consideration.

\section{Known Waste Sites}

Locations of known waste sites were rejected.

\section{Year Floodplain}

Areas within the 100-year floodplain were not considered.

\section{Hydrogeology.}

In assessing the hydrogeology criteria for sitc sclcction, three primary criteria were used.

\section{Upward Hydraulic Gradient}

The location must have an upward hydraulic gradicnt between the water table (unconfined) aquifer and the first underlying confined aquifer. The upward hydraulic gradi. ent is to ensure that contaminants entering the water table aquifer cannot continue downward into the underlying confined aquifer.

\section{Simple Groundwater Flow}

The groundwater flow pattern in the water table aquifer should be simple. Essentially, it should move horizontally, in one direction through the water table aquifer to a ncarby discharge point. This type of flow will minimize the spread of any potential contaminants. In addition, the flow direction in the shallowest confined aquifer should be in the same general direction (no more than $90^{\circ}$ out of phasc) as 


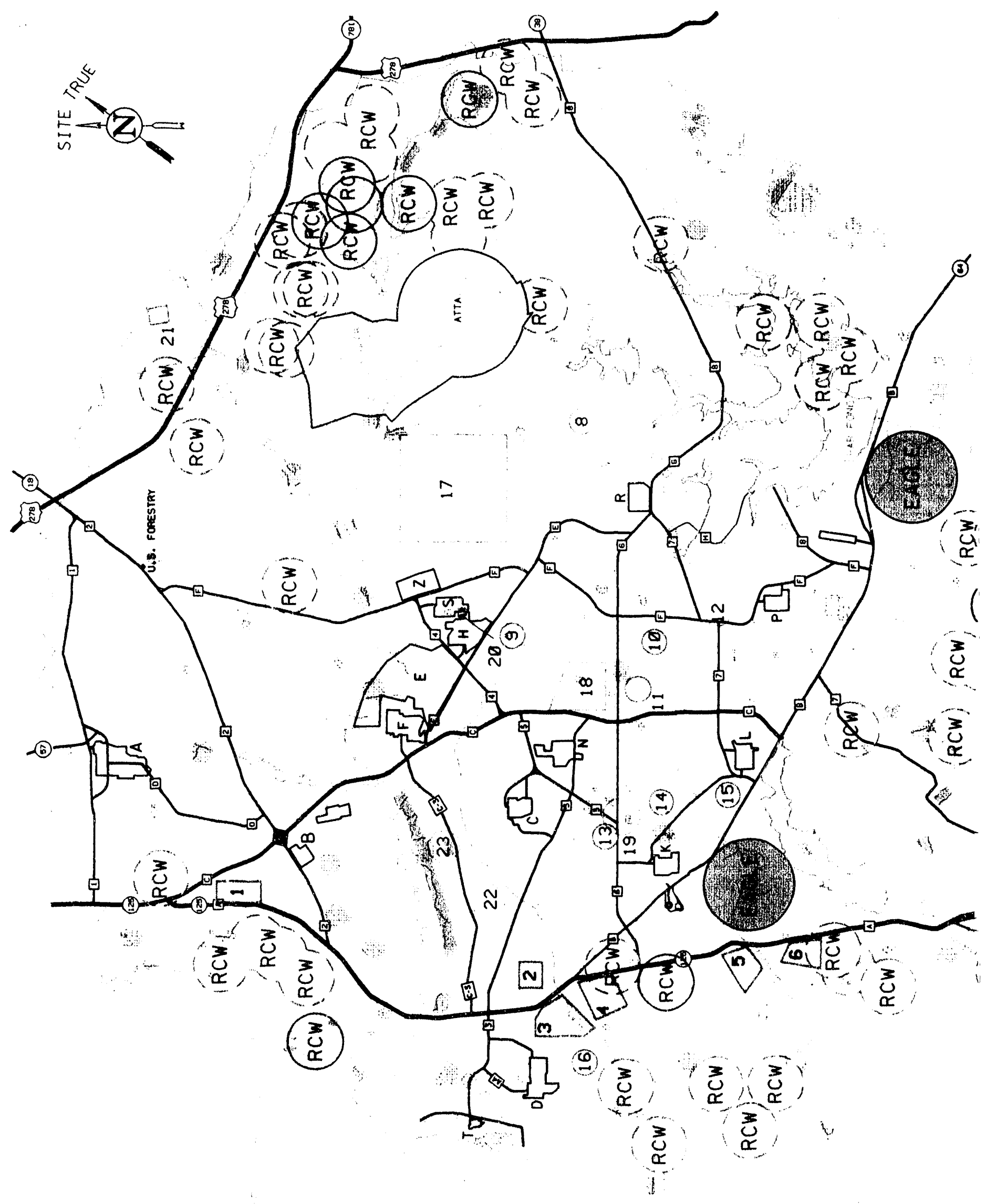



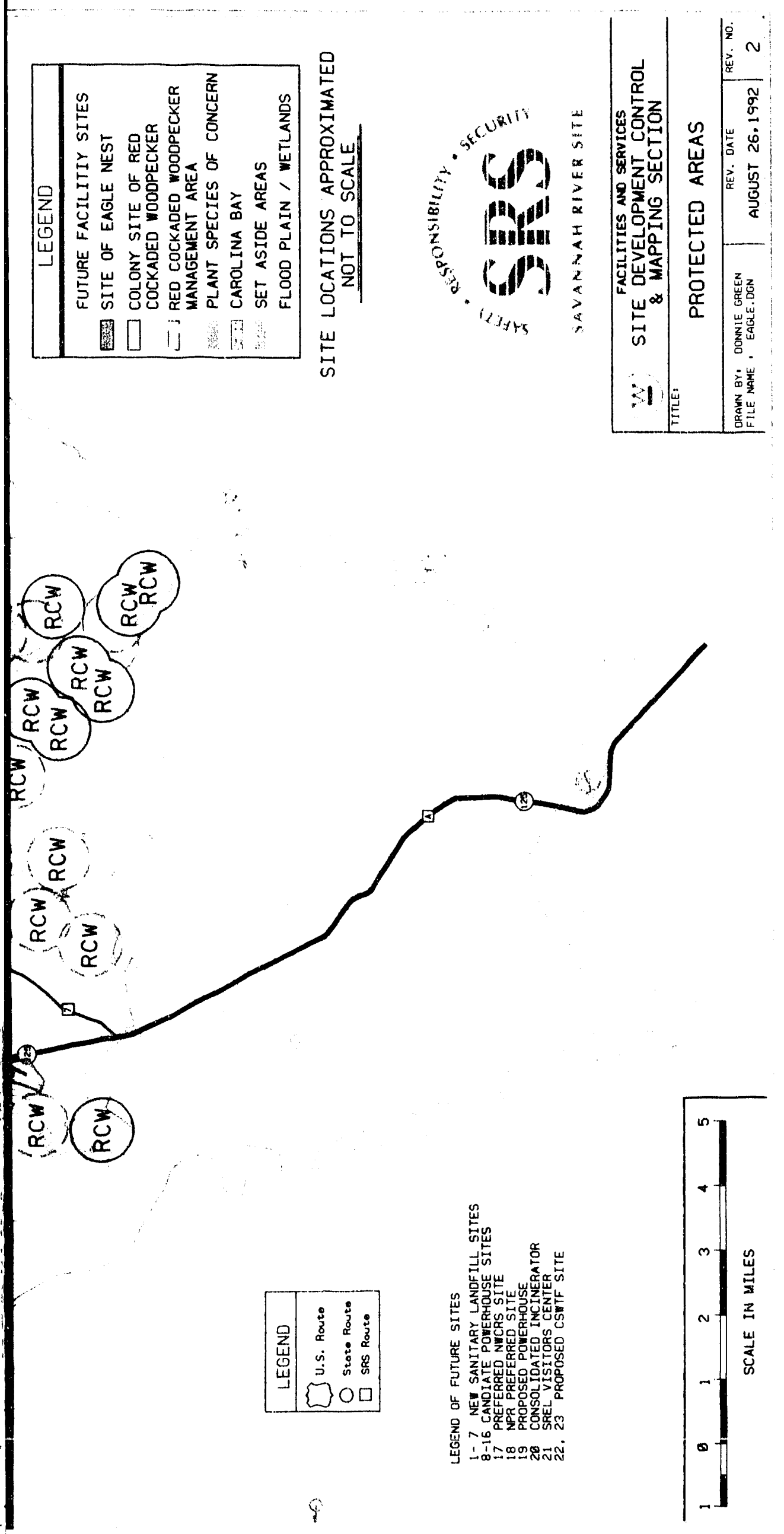
Figure 1. SRS Map Showing Exclusion Arcas 
the flow direction in the water table aquifer. The purposc of this restriction is to ensure a reasonably simplc hydrogeologic flow system should remediation become necessary.

\section{Continuous Confining Unit}

A continuous low-permeability confining unit must exist under the proposed landfill site that extends bcyond the boundary of the site proper to at least 400 feet in the upgradient and side-gradient directions and should be continuous in the down-gradient direction beyond the point where groundwater in the water table discharges to a surface stream. This is critical because it supports the SCDHEC requirement for flow in the water table to be only towards the nearby stream.

The confining unit should be at least 5 feet thick, have a hydraulic conductivity less than $1 \times 10^{-7} \mathrm{~cm} / \mathrm{sec}$, have a high-ion-exchange capacity, and a high organic carbon content.

\section{Screening Criteria and Weighting Fac- tor Determination}

The team sclected screening or ranking critcria to reflect specific areas of concern in determining the suitability of a site for location of the new facility. Geology, hydrogeology, surface hydrology, ecology, and engineering are the criteria categories. By consensus, the team assigned a weight to each category according to its relative importance in determining site suitability. For examplc, hydrogeology is weighted more than other categories because of the regulatory importance attached to hydrogcologic characteristics of a landfill site.

Each critcrion within each category received a valuation for maximum possible score, such that the sum of the products of the two factors for all criteria within a category equals the overall weight of the category as discussed above. The raw score for any given site for each criterion is the score relative to the maximum possible allowed by the weighting factor for that criterion. The site weighted score is the product of the raw score and the category weighting factor.

For all criteria a higher score is desirable. For cxamplc, if the maximum possible score defined for a critcrion was four and the site being considered was very desirable in respect to the specific characteristic being considered, it would reccive a score of four. If the category weighting factor was two for that criterion, the site would have a weighted score of eight, or the maximum possiblc score.
The categories and their criteria are discussed in detail bclow.

\section{Geology and Soils}

\section{Near Surface Bedrock}

Bedrock or bedrock features should not exist within 10 feet of the earth surface. This criterion does not restrain siting at SRS but is included in SCDHEC siting critcria. Bedrock is between 600 and 1200 feet deep under the SRS.

\section{Proximity to Active Fault}

The disposal unit should not be located less than 100() fect from a capable fault. This is not expected to restrain siting because no known capable faults, as defined by $10 \mathrm{CFR}$ 100 Appendix A, exist at SRS (Stieve et al. 1991).

\section{Proximity to Karst}

The disposal unit should not be located within 2 milcs of a Karst feature (sinkhole, loosing stream, cave, ctc.). This is included in SCDHEC siting criteria, but is not a concern at SRS and is not expected to restrain siting because no known Karst features exist at SRS.

\section{Surface Slope}

Surface slope is the inclination of the land surface from the horizon and is given in percentage points. Percent slope is the vertical distance divided by horizontal distance multiplied by 100 . Existing slope should be greater than $2 \%$ and less than $12 \%$ with an optimum slope of $7 \%$. Drainage incisions or deep swales through the site should be avoided. Optimum slope would benefit leachate collection-system design.

\section{Surface Erodibility}

Surface erodibility is a factor assigned to cach soil type published in the SRS Soil Survey Report (Rogers 1990) under Physical and Chemical Propertics of the Soils. The factor is based on the physical and chemical propertics of the soil as described in Table 12 of Rogers (1990). The lower the number, the lower the potential for that specific soil to erode. A Soil Conservation Service (SCS) crodibility factor of 0.20 is the greatest acceptable crosion poten. tial. 


\section{Hydrogeology}

The weighting factors assigned to the screening criteria for hydrogeology are greater than the screening criteria for other categories because of the regulatory importance attached to hydrogeologic characteristics of a landfill site. The category weighting factor assigned to all the hydrogeologic screening criteria is four. The category weighting factors for all the other screening criteria are two or less. Each of these criteria are included in SCDHEC siting requirements.

\section{Depth to Groundwater}

A minimum of 5 feet should separate the basc of the disposal unit and the seasonal-high water table. Sites with excessively deep water tables should be avoided. The weighting of this criterion was reduced because of the emphasis placed on an upward hydraulic head, which will require a site to be located in an area where a shallow water table exists.

\section{Flow Direction of Confined/Unconfined Units}

The flow direction of the groundwater in the water-table aquifer and the shallowest confined underlying aquifer should be in the same general direction.

\section{Simple Water-Table Flow}

The groundwater flow in the water-table aquifer should move one direction horizontally through the uppermost saturated unit above the shallowest confining unit, and discharge to surface water near the site edge. The time of travel for groundwater migrating from the down-gradient edge of the waste management unit to the discharge point should be greater than or equal to four years. This is one of the highest ranked hydrogeological criteria bccause it supports the SCDHEC requirements.

\section{Upward Hydraulic Gradient}

The groundwater hydraulic head in the shallowest confined aquifer should be higher than that in the water table just above it. This is t':e highest ranked hydrogeological critcrion. This requ.iement forms the basis of the SCDHEC requirements.

\section{Ground water Use}

The disposal unit should not be less than 500-fect down gradient, 750-feet side gradient, or at any distance hydraulically up gradient of an existing or planned groundwater use. All of the proposed sites meet this criterion.

\section{Continuous Confining Unit}

A continuous low-permeability confining unit should cxist under the disposal unit. The confining unit should be continuous at least 400 feet beyond the boundary of the landfill proper in the up- and side-gradient directions and beyond the point where shallow groundwater above the confining unit discharges to surface water in the down-gradient direction. This is one of the highest-ranked hydrogeological criteria because it supports the SCDHEC requirements. This will become a screening critcrion in the second round of scoring after subsurface characterization.

\section{Thickness of Confining Unit}

The unit should be at least 5-feet thick, have a hydraulic conductivity less than $1 \times 10^{-7} \mathrm{~cm} / \mathrm{s}$, have a high ionexchange capacity, and a high organic carbon content. In the immediate area of the various potential sites, gencrally within 1500 feet, data from wells penetrating to basement were examined to determine if the water-table aquifer at the site is scparated from the underlying shallowest confined aquifer by a confining unit that mects the critcrion established by SCDHEC. All seven sites met the critcrion for minimum thickness, assuming that the wells cxamined are indicative of the stratigraphy at the proposed site locition. The estimation of hydraulic conductivity, ionexchange capacity, and organic carbon content of the confining unit can only be assessed after charactcrizing the specific site in the second phase of the selcction process.

\section{Absence of High Conductivity Zone}

A highly transmissive zone should not be present within 50 feet of the surface or $\mathbf{5 0}$ feet of the basc of a proposed landfill. A zone or bed that has a transmissivity 500 times greater than is typically encountered in the arca near the site should be considered highly transmissivc. This can only be adequately addressed after characterizing specific sites during the second phase of the site sclection process.

\section{Surface Hydrology}

The first three criteria in this section support the SCDHEC requirements. Surface hydrology considerations are lim. ited to adjacent stream parameters.

\section{Stream Proximity}

The disposal unit should be located no more than 1,500 feet from a flowing stream. Sites closer to streams reccive higher scores. 


\section{Stream Quality}

The disposal unit should be located in a manner such that the destruction or degradation of high-quality streams is avoided. This criterion was added to prevent the location of a disposal unit within the headwaters of high-quality water courses. Sites on or near degraded stream systcms receive higher scores.

\section{Stream Flow}

The flowing surface water should have a $7 \mathrm{Q} 10$ flow greater than $3 \mathrm{cfs}$. Higher scores are awarded for flows above this minimum.

\section{Year Floodplain}

The disposal unit should not be located within the 100 year floodplain, therefore the actual floodplain was used as an exclusion criterion. However, sites are scored on their distance from the floodplain, with greater distance rcceiving higher scores.

\section{Ecology}

Ecological considerations are always important in location of any major facility. The SRS has numerous sensitive ecological features including areas where plants and animals of concern can be found, endangered specics and their management areas, pristine headwater streams, wctlands, and ecological research set-aside areas. All of these facets of the ecological resources of SRS must be considered in siting any major project.

\section{Aquatic Ecology}

To reduce the impact to the ecosystem caused by potential leachate outcropping, the site should be in an arca that would minimize the impacts to aquatic life in the event of a breach or failure of the liner system. This is the highestranked ecological criterion. Sites near higher-quality streams would score lower than those sites situated near streams with current or past impacts.

\section{Terrestrial Ecology}

The location and operation of the disposal unit should minimize impacts to plant and animal species located around the disposal-unit area and not threaten or degrade current conditions. Site location should avoid areas containing high-value, limited-availability resources and communities. A site in an area of early growth pine plantation or recent clear-cut would have minimal terrestrial resource value and would score highly for this criterion.

\section{Set Asides}

The disposal unit should not be located in an area which would impact nearby ecological set-aside areas. Rescarch activities and biotic communities can be sensitive to adjacent disturbances; sites farther away from sct asides will score higher than those nearer to areas of interest.

\section{Wetlands Ecology}

The location of the disposal unit should avoid or minimizc loss of wetlands. This is included in the SCDHEC siting criteria. Even though loss of wetlands must be minimized, impact to nearby wetlands is a possibility due to the nature of the SCDHEC hydrogeologic guidance. Sites nearer to lower-quality wetlands, for example those associated with degraded streams, will score higher than sites near higherquality wetlands.

\section{Engineering}

This section delineates the engineering and technical criteria necessary to ensure safe and efficient operation of the NSL. Many of these criteria are derived from the SCDHEC guidelines.

\section{Borrow Availability}

Suitable liner $\left(1 \times 10^{-7}\right)$, cap $\left(1 \times 10^{-7}\right)$, and daily cover material should be available on or near $(<0.5 \mathrm{mi}$.) the disposal unit boundary. Should adequate liner or cap matcrial not exist, alternative sources for this matcrial will be considered if a legally binding contract is provided. This critcrion is included in the SCDHEC siting critcria. Although any soil may be used for daily cover, a low-permeability soil would be preferred.

\section{Drainage Availability}

Suitable drainage layer media should be available on or near ( $<0.5 \mathrm{mi}$.) the disposal unit boundary. This is not a regulatory requirement.

\section{Topsoil Availability}

A loamy soil should exist in suitable quantity. This is not a regulatory requirement.

\section{Archaeology}

The disposal unit should be located no less than $200 \mathrm{fcct}$ from archaeological resources; distances of 500 fect or more are ideal. Candidate sites were evaluated for potential archacological impact using Brooks ct al. (1989) to 
determine percent of each site occupying each of the three different archaeological sensitivity zones. Sites with morc area in sensitivity Zone 3 received higher scores than those with less area in Zone 3 or significant areas in Zones 1 or 2 . This is an important criterion because of its ability to inflict major schedule delays on the project. A walkdown evaluation by members of the Savannah River Archaeological Research Program before major activity begins on any site is highly recommended.

\section{Proximity to Primary Roads}

The disposal unit should not be less than 200 feet from a primary road (road class) corridor.

\section{Proximity to Utility Corridors}

A site should be selected which avoids major utility corridors through the site. Electrical service, water, sewer, and communication facility access is essential to operation of the facility and should be nearby. A separation distance of 500 feet is ideal, less than 200 feet and greater than 1000 feet are unfavorable.

\section{Proximity to Waste Source}

The disposal unit should be located near the main administration area.

\section{Proximity to Airports/Heliports}

The site must be more than 10,000 feet from an airport/ heliport that handles turbojet aircraft and more than 5000 feet from a facility that handles piston-driven aircraft. This criterion is defined by Resource Conservation and Recovery Act subtitle D. Regulations (40 CFR 258).

\section{Security}

The disposal unit should be located in an area where unauthorized access can be controlled and protection of material and equipment can be maintained.

\section{Public Exposure}

The disposal unit should be located in an area which prohibits exposure to the public.

\section{Available Area}

The disposal unit should have a minimum of 100 acres of usable area. This criterion is essential to providing SRS a disposal unit for the next 20 years.

\section{Compatible Land Use}

The disposal unit should be located in an area where the proposed facility is compatible with existing land use patterns and will minimize impacts to the surrounding arca. This criterion was added to help evaluate the impact of a facility when located near other facilities or land use arcas.

\section{Site Ratings}

Sites were rated for each of the 33 criteria using best available data, professional judgement, and site visits and walkdowns where applicable. Raw scores werc assigned based on total possible points available as set by the critcria weighting factors.

\section{Nondiscriminating Criteria}

Of the 33 criteria, 15 are nondiscriminating. Nondiscrimination results when all sites receive the same score for a specific criterion. Nondiscriminant criteria included the following:

- near surface bedrock

- proximity to active faults

- proximity to Karst

- groundwater use

- continuous confining unit ${ }^{1}$

- thickness of confining unit ${ }^{1}$

- absence of high-conductivity zone ${ }^{1}$

- aquatic ecology

- set-asides

- borrow availability

- top soil availability

- proximity to primary roads

- proximity to utility corridors

- security

- public exposure

\section{Discriminating Criteria}

The remaining 18 criteria were discriminating, which means that not all sites received the same score for any chosen criterion. The following subscctions discuss the seven site ratings for the 18 discriminating critcria.

1. Based on preliminary professional judgements; definitive scoring will occur following subsurfarc characterization. 


\section{Surface Slope}

Site 1 has a slope range of 1 to $6 \%$ and an average slope of $4 \%$, it shares a maximum rating with Sites 2 and 4 because their slopes fall within the defined optimum range. Site 2 has a slope of 3 to $4 \%$ and Site 4 has an average of 3 to $4 \%$ siope; however, approximately $10 \%$ of the area, mostly along Four Mile Creek, has slopes of 10 to 20\%. Site 3 gets no points for slope because it has nearly level land with slopes of 0 to $1 \%$ over most of the area. Sites 5,6 , and 7 have intermediate to poor ratings because they tend to have less slope than is considered optimum, magnitude of point deduction depends upon deviation from the preferred slope. Site 5 has slopes of 1 to $3 \%$ over most of the area with a small area of approximately 10 acres having slopes of 6 to 15\%. Most of Site 6 has slopes in the range of 1 to $3 \%$. Site 7 has a slope range from 0 to $3 \%$ over most of the area.

\section{Surface Erodibility}

The surface soils of Sites 1, 2, and 3 are all sandy and have an erodibility factor of 0.10 . All soils of Site 7 also have erodibility factors of 0.10 or less. These sites all received maximum possible points. Sites 4 through 6 received slightly reduced points due to certain features of their surface erodibility. The surface erodibility of Site 4 is 0.10 in about $85 \%$ of the area and about $10 \%$ has a factor of 0.24 , the other $5 \%$ is wetlands and is not in a position to erode but will receive sediment. About $95 \%$ of Sites 5 and 6 have erodibility factors of 0.10 , the remaining $5 \%$ have factors of 0.24 .

\section{Depth to Groundwater}

Proposed Site Locations 2 and 3 received a score of 0.25 because these locations are topographically low, close to the Four Mile Branch flood plain, and, therefore, very close to the water table. Site 1 received a score of 0.25 because it may have excessively deep groundwater. The remaining site locations received the highest score of 0.5 .

\section{Flow Direction of Confined/Unconfined Units}

The weighted score for flow direction of confined/unconfined units indicates that at all the proposed site locations, except Site 1, the flow direction in the water-table aquifer and the underlying shallowest confined aquifer are similar (within $90^{\circ}$ of each other) but not parallel to one another. These locations received a score of 0.5 . Only Site 1 received a score of 1 where the flow direction of the two aquifers is considered to be parallel.

\section{Simple Water Table Flow}

The hydraulic gradient map of the water table and the hydraulic gradient map of the underlying shallowest confined aquifer (Gordon Aquifer) from which the hydraulic gradient difference map (Figure 2) was constructed were used to estimate the flow direction of groundwatcr in cach aquifer. The score for Simple Water Table Flow was the maximum at each proposed site location except Site 1 . Site 1 has a score of 0.5 , because there may be radial flow. The criterion for acceptable simple groundwater flow directions between the two aquifers was for a flow direction that was within $90^{\circ}$ of each other.

\section{Upward Hydraulic Gradlent}

For the initial SRS sitewide screening for proposcd landfill locations, the ESS Geotechnology group constructed a hydraulic-gradient difference map (head difference map) between the water table (unconfined) aquifcr and the underlying shallowest confined aquifer (Figure 2). All the unshaded areas on the map with positive valucs, indicate areas of upward gradient and were considered for siting purposes. The score indicates that Sites 2, 3, 5, 6 and 7 had the highest possible score, being located well within the area of upward hydraulic gradient. Site 1 with a score of 1 is located very close to the $\mathbf{0}$ contour on the head difference map indicating inconclusive head reversal at the sitc location. Similarly, Site 4 with a score of 1.5 may have a portion of the site in areas of inconclusive upward hydraulic gradient.

\section{Stream Proximity}

Linear map distance from the nearest stream was used to score the sites for this criterion. Site 1 reccived no points because it was greater than 1500 fect from any strcam. Individual site scores reflect this distance with the sitc closest to a stream (Site 5) receiving a maximum scorc.

\section{Stream Quality}

Because Sites 2, 3, and 4 are adjacent to Four Mile Creek, a degraded system, they received maximum scorcs. Sitc 1 also received a score of 3 because it is not ncar any strcam. Sites 5 and 6 are adjacent to Pen Branch which is also a degraded system giving them nearly maximum scores. Site 7 is adjacent to the Steel Creek/ Meycrs Branch system which is much less degraded than the other stream systems, giving the site a score of 0 . 


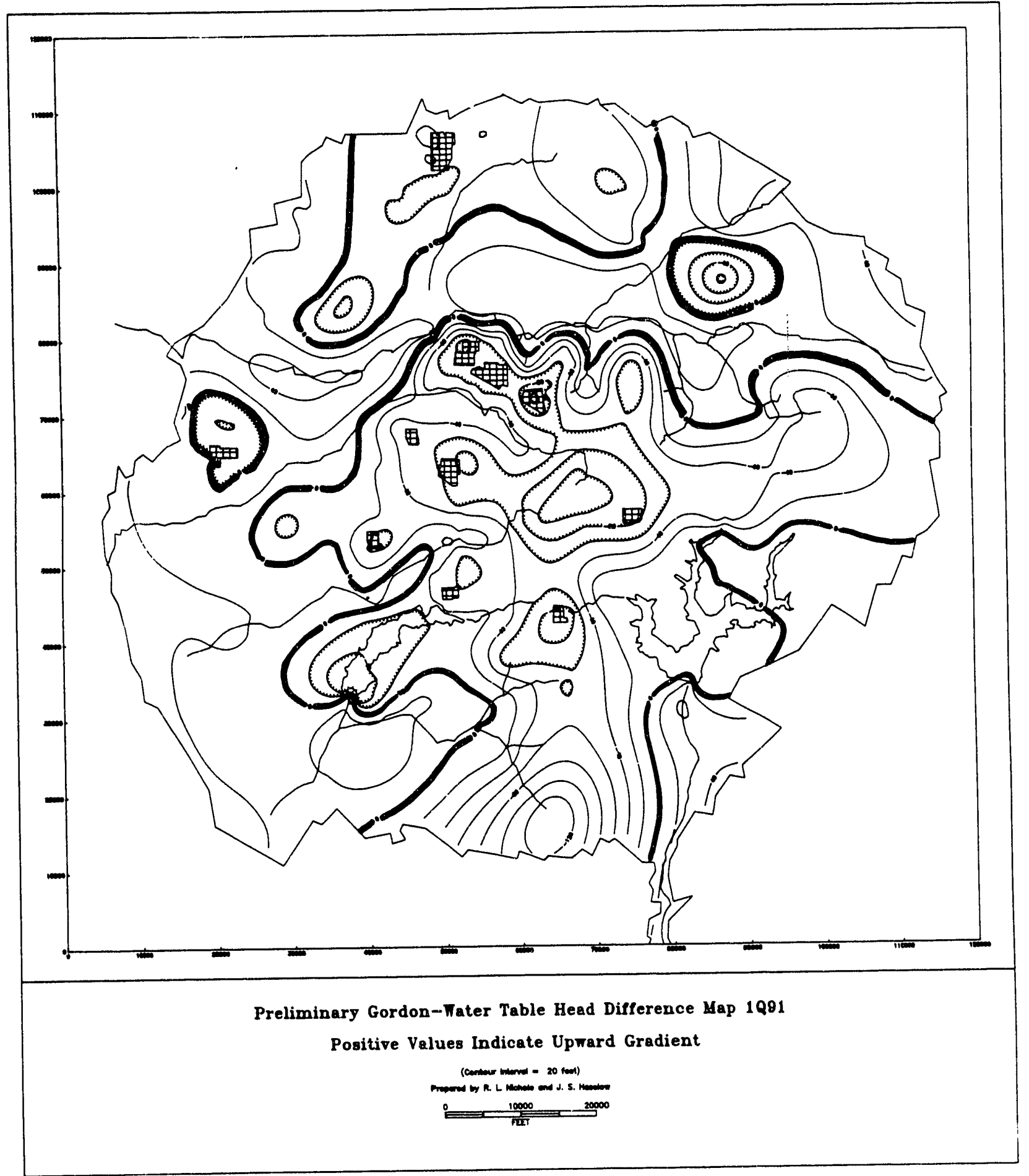

Figure 2. Hydraulic Gradient Difference Map 


\section{Stream Flow}

Sites 2, 3, and 4 are located near Four Mile Creek and received similar ratings. Sites 5 and 6 received a higher rating because they are near Pen Branch, which has a higher flow than Four Mile Creek. Site 7 received a rating of 1 because it is near Steel Creek, which has a flow less than the other two creeks. Site 1 received a 0 because it is not near a creek.

\section{0-Year Floodplain}

Sites 1 through 4 are slightly farther away from the 100 year floodplain than are the other sites giving them full points while Sites 5, 6, and 7 have lower scores.

\section{Terrestrial Ecology}

Sites 1, 2, 3, 5, and 7 all received maximum scores. Sites 1 and 2 are primarily pine plantation. Site 3 has recently been clear-cut. Site 5 had been a soil-borrow area, and because of the lack of good soil the existing upland vegetation is of very poor quality. The upland areas of Site 7 are covered mainly by pine plantation. Site 4 has a small amount of higher-quality upland habitat and, therefore, received a somewhat reduced score. Site 6 received the lowest score because it has some older-growth pine forests that constitute potential red-cockaded woodpecker habitat.

\section{Wetlands Ecology}

Site 7 received no points for the wetlands criterion because approximately $30 \%$ or more of the site area is covered by wetland habitat. Site 6 contains a Carolina bay and some associated hardwood area and, therefore, received a reduced score. Site 4 has a minimal amount of hardwood areas and received a slightly diminished score. The remaining Sites $1,2,3$, and 5 , all contained no wetlands and received maximum scores.

\section{Drainage Availability}

Information from the soil survey was used to weight the predominate soil type to determine if adequate sand or gravel was present to use as a source of drainage media for the liner/cap system, drainage facilities, and controlled construction material. Each of the seven sites scored just above the mid-range. Site 4, I which contains a somewhat larger variety of soil types, received a slightly lower ranking due to the low soil hydraulic sonductivity of some of the soils within the site. The criteriol rankings will be confirmed during subsurface investigatios .

\section{Archaeology}

Site 7 received no points because nearly all of the site area is in sensitivity Zone 1 . Site 5 received a very low score because its area is nearly evenly divided between sensitivity Zones 1 and 2. Site 3's score is based on the fact that most of site is in sensitivity Zone 2 with the remainder in Zone 1 . The majority of Site 4 is in sensitivity Zone 2 . Site 6 scores better even though much of its area is in Zone 2, the remainder is in Zone 3. Site 2 loses minimal marks because its area is evenly divided between Zones 2 and 3 . Site 1 gets a perfect score because almost all of its area is in sensitivity Zone 3.

\section{Proximity to Waste Source}

The purpose of this category is to determine which site is closest to the largest waste source at SRS. The two largest generators of sanitary waste at SRS are the main administrative area and Central Shops. Site 1 scored the highest because it is the closest to these areas. Site 7 scored the lowest for this criterion because it is the most remote of the candidate sites. The scores were calculated based upon the percentage of the distance from the main administrative area to Site 1 . Sites 2 through 6 are relatively equal with Site 5 being the farthest away of this remaining group.

\section{Proximity to Airports/Heliports}

All of the sites except Site 1 scored the maximum for this criterion. Site 1 is located within the 10,000 foot zone required for location of disposal units.

\section{Available Area}

Preliminary calculations indicate a minimum of 100 acres is necessary to support the disposal unit. All sites met the minimum requirements and were then scored based on their total available area.

\section{Compatible Land Use}

Scoring for this criterion was based upon the candidate site's proximity to other land use areas. Sites 2, 4, 5, 6, and 7 are all located in areas relatively removed from other facilities and, therefore, received maximum scores. Sites 1 and 3 are somewhat closer to areas of activity; Sitc 1 is located near a main gate and between two heavily travelled roads, Site 3 is located relatively close to $400-D$ Area. Sites 1 and 3 received somewhat reduced scores based on their locations. 


\section{Conclusions and Recommendations}

\section{Final Site Ranking}

The results of each site evaluation for all criteria appear in Tables 1 and 2. Raw scores (Table 1) for each site reflect the portion of the total possible points for the specific criterion and the desirability relationships between the sites. The weighted scores (Table 2) are the product of the individual site's raw score and the category weighting factor for the criterion being considered. Subtotals by category are simply the sum of weighted scores by site and the total site score is the sum of the category scores.

\section{Site comparison by categories}

Figure 3 shows comparison of sites by category. Surface hydrology, geology and soils, and engineering show the most variation between sites. Hydrogeology and Ecology show little difference between most sites. Sites 6 and 7 have significant amounts of wetland areas that account for their lower Ecology category scores. The evenness of the hydrogeology scores can only be satisfactorily resolved by adequate subsurface characterization.

\section{Site comparison by total score}

Table 3 shows total and category scores for each site. Total scores indicate that Sites 2, 3, 4, and 5 are essentially equivalent based on the current analysis. According to the current level of the site selection process, any of these four sites would be suitable for further characterization.

\section{Recommendation}

The team recommends that two of the four potentially suitable sites-Sites $2,3,4$, and 5-be chosen for subsurface characterization. It is further suggested that the two chosen sites be characterized in parallel so that any encountered flaws in either site will not impact important time constraints by requiring a new subsurface characterization to be begun. Even if both sites prove to be acceptable after the subsurface characterization, the dual characterization would not prove to be a false economy since the completely evaluated second site would be available for other projects or facilities. It is the general consensus of the committee that Sites 3 and 5 be chosen for the next stage of site selection and that subsurface characterization be undertaken at these sites. Sites 2, 3, and 4 are very close together; Site 3 was chosen for characterization because of its larger size. Additionally, Site 3 was expected to possess a stronger upward hydraulic gradient than either sites 2 or 4 .

\section{Subsurface Investigation}

For the initial screening and characterization of the two sites selected, three geotechnical bore holes will be drilled up to 360 feet deep at each site and shallow seismic reflection surveys will be conducted. The bore holes will be continuously cored, and geophysically logged in order to delineate the stratigraphy of the site. WSRC will attempt 20 Electrical Cone Penetration Testing holes up to 120 feet deep to further define the stratigraphy of each site. In addition, nine PVC wells drilled as three, three-well clusters, up to 360 feet deep, to be used primarily to collect water elevation information, and water quality samples if deemed necessary by WSRC. Tests (aquifer and grain size analysis) to establish hydraulic conductivity and porosity will be conducted at the preferred site after initial screening is completed.

\section{Acknowledgments}

The team wishes to gratefully acknowledge the editorial support of Richard Shipley and the desktop publishing support of Trish Baughman of the Technical Publications Group of the Management Services Department. The tcam also wishes to acknowledge the assistance of Donnie Green of the Facilities and Services Department of the Site Services Division for his support and excellent maps.

\section{References}

Brooks, M. J., R. D. Brooks, K. E. Sassman, G. S. Lewis, D. R. Robinson, G. T. Hanson, D. G. Anderson. South Carolina Institute of Archaeology and Anthropology, Archaeological Resource Management Plan of the Savannah River Archaeological Research Plan. Savannah River Archaeological Research Program, South Carolina Institute of Archaeology and Anthropology, University of South Carolina, 1989.

Code of Federal Regulations, 10 CFR 100 Appendix A, 1982, Seismic and geologic siting criteria for nuclear power plants: Office of the Federal Register, National Archives and Records Administration.

Code of Federal Regulations, 40 CFR 258 RCRA Subtitle D Regulations: Office of the Federal Register, National Archives and Records Administration.

DOI (U. S. Department of the Interior) U.S. Fish \& Wildlife Service Mitigation Policy, 84 ISM2 Chapter 2, 1981.

Hillestad, H. O., S. H. Bennett, Jr. Sct Aside Arcas National Environmental Research Park, Savannah River Plant, Aiken, South Carolina, 1982.

Muthig, M. G., Guidelines For Establishing The Hydrogeologic Acceptability of Proposed Sites For Industrial And Domestic Waste Landfills, December 1990 
Interim Final, SCDHEC, Hydrogeology Division, Superfund \& Solid Waste Section, 1990.

Rogers, V. A., Soil Survey of Savannah River Plant Area, Parts of Aiken, Barnwell, and Allendale Counties, South Carolina, USDA-SCS, June 1990.

Stieve, A. L., Stephenson, D. E., Aadland, R. K., 1991, Pen Branch Fault: Consolidated Report on the Seismic Reflection Surveys and the Shallow Drilling (U),
WSRC-TR-91-87, Savannah River Laboratory, Aiken, South Carolina.

Westinghouse Savannah River Company, Site Hydrogeologic/Geotechnical Characterization Report for Site B New Municipal Solid Waste Landfill (U), WSRC-RP91-392, Savannah River Site, Aiken, South Carolina, April 1991. 


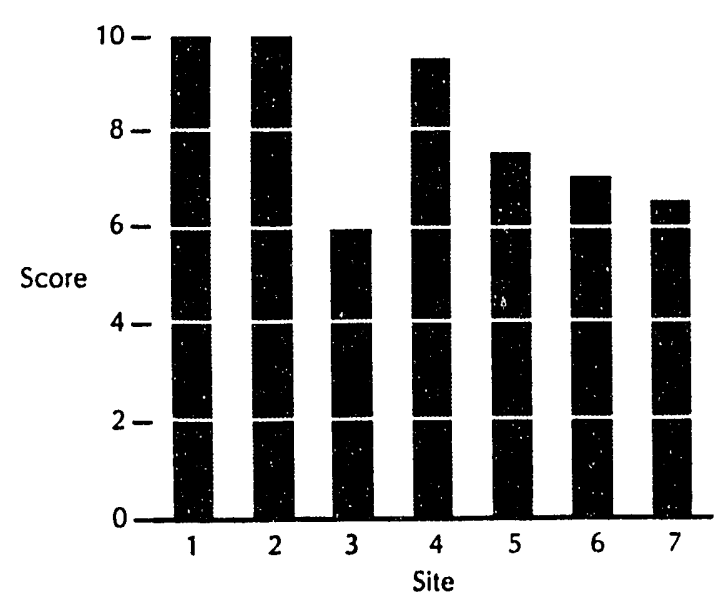

Geology and Soils

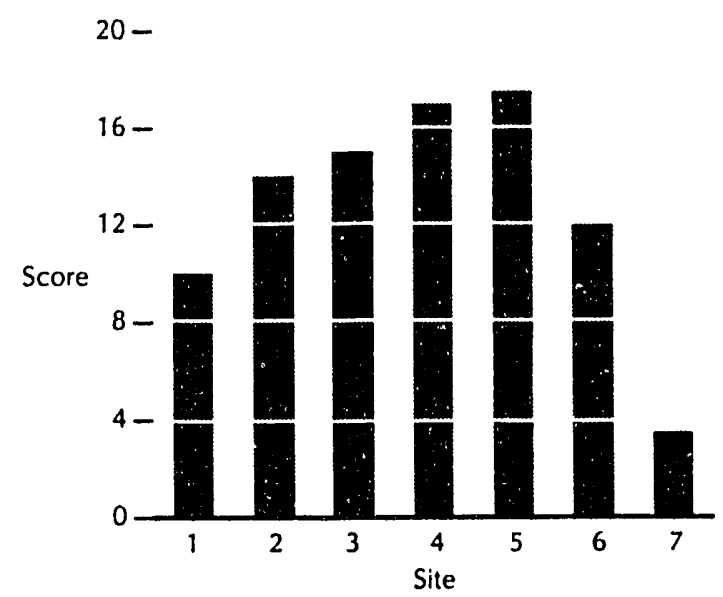

Surface Hydrology

$10-$

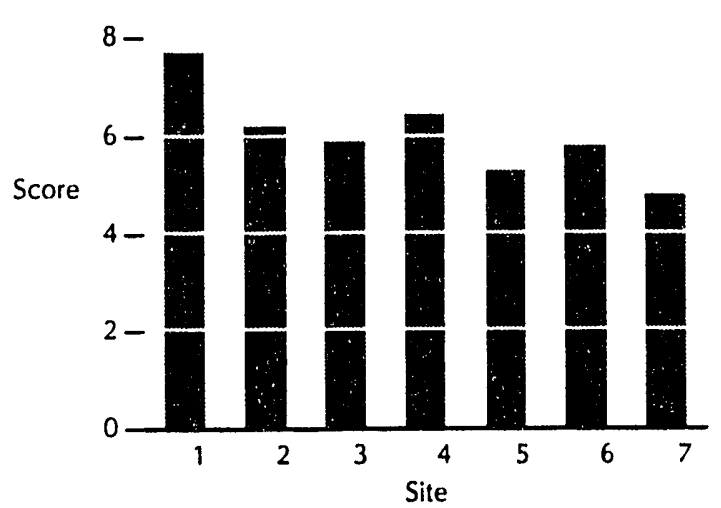

Engineering

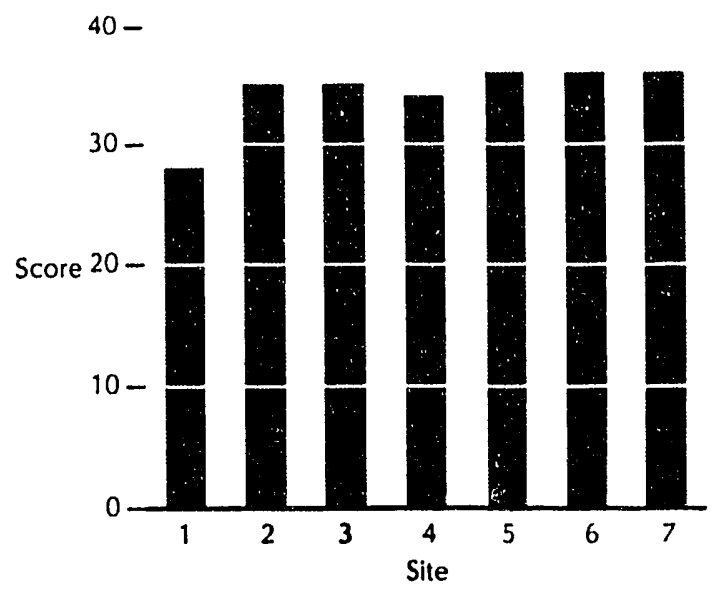

Geohydrology

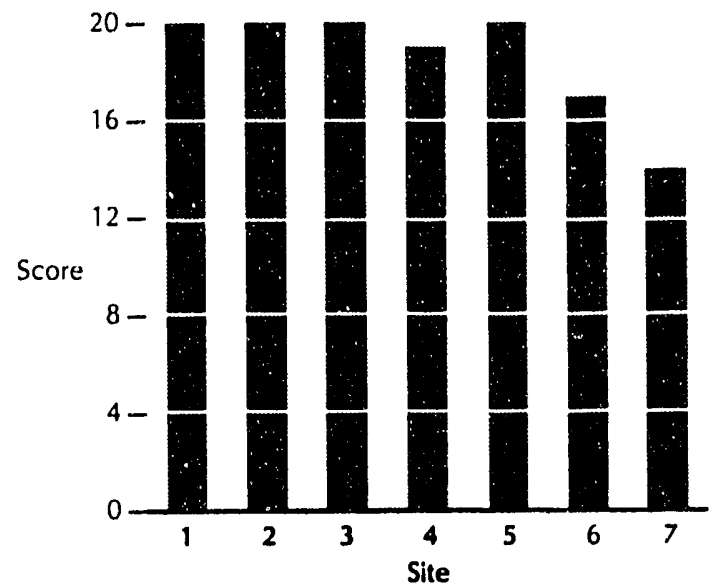

Ecology

$100-$

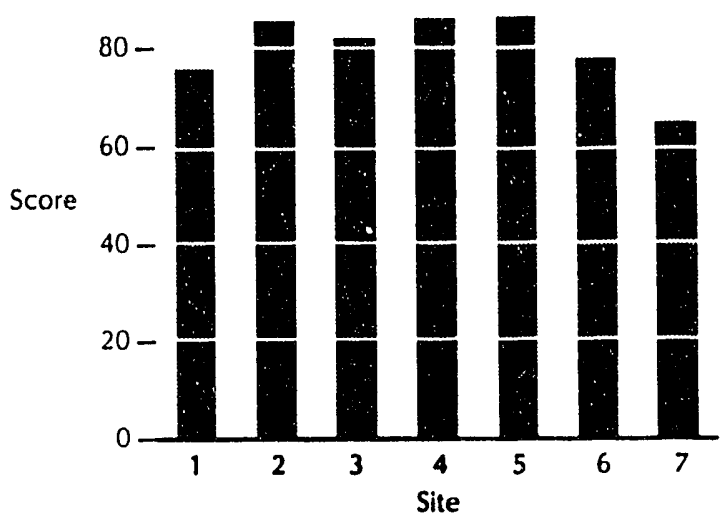

Total

Figure 2. Site Selection Criteria Categories and Total Scores 
Table 1. Raw Scores for Sitc Selection Criteria

\begin{tabular}{|c|c|c|c|c|c|c|c|c|c|}
\hline \multirow[b]{2}{*}{ Criteria } & \multicolumn{2}{|c|}{ Weighting Factor } & \multicolumn{7}{|c|}{ Site } \\
\hline & Category & Criteria & 1 & 2 & 3 & 4 & $\mathbf{5}$ & 6 & 7 \\
\hline \multicolumn{10}{|l|}{ Geology and Soils } \\
\hline Near surface bedrock & 1.00 & 0.50 & 0.50 & 0.50 & 0.50 & 0.50 & 0.50 & 0.50 & 0.50 \\
\hline Proximity to active fault & 1.00 & 2.00 & 2.00 & 2.00 & 2.00 & 2.00 & 2.00 & 2.00 & 2.00 \\
\hline Proximity to karst & 1.00 & 0.50 & 0.50 & 0.50 & 0.50 & 0.50 & 0.50 & 0.50 & 0.50 \\
\hline Surface Slope & 1.00 & 4.00 & 4.00 & 4.00 & 0.00 & 4.00 & 2.00 & 1.50 & 1.00 \\
\hline Surface erodibility & 1.00 & 3.00 & 3.00 & 3.00 & 3.00 & 2.50 & 2.50 & 2.50 & 3.00 \\
\hline \multicolumn{10}{|l|}{ Hydrogeology } \\
\hline Depth to groundwater & 4.00 & 0.50 & 0.25 & 0.25 & 0.25 & 0.50 & 0.50 & 0.50 & 0.50 \\
\hline $\begin{array}{l}\text { Flow direction conf./unconf. } \\
\text { units }\end{array}$ & 4.00 & 1.00 & 1.00 & 0.50 & 0.50 & 0.50 & 0.50 & 0.50 & 0.50 \\
\hline Simple water table flow & 4.00 & 2.00 & 0.50 & 2.00 & 2.00 & 2.00 & 2.00 & 2.00 & 2.00 \\
\hline Upward hydraulic pressure & 4.00 & 2.50 & 1.00 & 2.00 & 2.00 & 1.50 & 2.00 & 2.00 & 2.00 \\
\hline Groundwater use & 4.00 & 0.50 & 0.50 & 0.50 & 0.50 & 0.50 & 0.50 & 0.50 & 0.50 \\
\hline Continuous confining unit & 4.00 & 2.00 & 2.00 & 2.00 & 2.00 & 2.00 & 2.00 & 2.00 & 2.00 \\
\hline Thickness of confining unit & 4.00 & 1.00 & 1.00 & 1.00 & 1.00 & 1.00 & 1.00 & 1.00 & 1.00 \\
\hline Absence of high conduct zone & 4.00 & 0.50 & 0.50 & 0.50 & 0.50 & 0.50 & 0.50 & 0.50 & 0.50 \\
\hline \multicolumn{10}{|l|}{ Surface Hydrology } \\
\hline Stream proximity & 2.00 & 3.00 & 0.00 & 0.50 & 1.00 & 2.00 & 3.00 & 0.25 & 1.00 \\
\hline Stream quality & 2.00 & 3.00 & 3.00 & 3.00 & 3.00 & 3.00 & 2.00 & 2.00 & 0.00 \\
\hline Stream flow & 2.00 & 3.00 & 0.00 & 2.50 & 2.50 & 2.50 & 3.00 & 3.00 & 1.00 \\
\hline 100-year floodplain & 2.00 & 1.00 & 1.00 & 1.00 & 1.00 & 1.00 & 0.75 & 0.75 & 0.75 \\
\hline \multicolumn{10}{|l|}{ Ecology } \\
\hline Aquatic ecology & 2.00 & 3.50 & 3.50 & 3.50 & 3.50 & 3.50 & 3.50 & 3.50 & 3.50 \\
\hline Terrestrial ecology & 2.00 & 1.00 & 1.00 & 1.00 & 1.00 & 0.75 & 1.00 & 0.50 & 1.00 \\
\hline Set asides & 2.00 & 2.50 & 2.50 & 2.50 & 2.50 & 2.50 & 2.50 & 2.50 & 2.50 \\
\hline Wetlands ecology & 2.00 & 3.00 & 3.00 & 3.00 & 3.00 & 2.75 & 3.00 & 2.00 & 0.00 \\
\hline \multicolumn{10}{|l|}{ Engineering } \\
\hline Borrow availability & 1.00 & 0.50 & 0.30 & 0.30 & 0.30 & 0.30 & 0.30 & 0.30 & 0.30 \\
\hline Drainage layer availability & 1.00 & 0.50 & 0.40 & 0.40 & 0.40 & 0.30 & 0.40 & 0.40 & 0.40 \\
\hline Topsoil & 1.00 & 0.50 & 0.20 & 0.20 & 0.20 & 0.20 & 0.20 & 0.20 & 0.20 \\
\hline Archaeology & 1.00 & 2.00 & 2.00 & 1.50 & 0.50 & 0.75 & 0.10 & 1.00 & 0.00 \\
\hline Proximity to primary roads & 1.00 & 0.50 & 0.50 & 0.50 & 0.50 & 0.50 & 0.50 & 0.50 & 0.50 \\
\hline Proximity to utility corridors & 1.00 & 0.50 & 0.50 & 0.50 & 0.50 & 0.50 & 0.50 & 0.50 & 0.50 \\
\hline Proximity to waste sources & 1.00 & 1.00 & 1.00 & 0.40 & 0.40 & 0.30 & 0.30 & 0.20 & 0.10 \\
\hline Proximity to airport/heliports & 1.00 & 0.50 & 0.30 & 0.50 & 0.50 & 0.50 & 0.50 & 0.50 & 0.50 \\
\hline Security & 1.00 & 0.50 & 0.30 & 0.30 & 0.30 & 0.30 & 0.30 & 0.30 & 0.30 \\
\hline Public Exposure & 1.00 & 1.00 & 0.30 & 0.30 & 0.30 & 0.30 & 0.30 & 0.30 & 0.30 \\
\hline Available area & 1.00 & 2.00 & 1.50 & 0.80 & 1.60 & 2.00 & 1.40 & 1.10 & 1.20 \\
\hline Compatible land use & 1.00 & 0.50 & 0.40 & 0.50 & 0.40 & 0.50 & 0.50 & 0.50 & 0.50 \\
\hline
\end{tabular}


Table 2. Weighted Scores for the Site Selection Criteria

\begin{tabular}{|c|c|c|c|c|c|c|c|c|c|}
\hline & Category & Criteria & 1 & 2 & 3 & 4 & 5 & 6 & 7 \\
\hline \multicolumn{10}{|l|}{ Geology and Soils } \\
\hline Near surface bedrock & 1.00 & 0.50 & 0.50 & 0.50 & 0.50 & 0.50 & 0.50 & 0.50 & 0.50 \\
\hline Proximity to active fault & 1.00 & 2.00 & 2.00 & 2.00 & 2.00 & 2.00 & 2.00 & 2.00 & 2.00 \\
\hline Proximity to karst & 1.00 & 0.50 & 0.50 & 0.50 & 0.50 & 0.50 & 0.50 & 0.50 & 0.50 \\
\hline Surface Slope & 1.00 & 4.00 & 4.00 & 4.00 & 0.00 & 4.00 & 2.00 & 1.50 & 1.00 \\
\hline Surface erodibility & 1.00 & 3.00 & 3.00 & 3.00 & 3.00 & 2.50 & 2.50 & 2.50 & 3.00 \\
\hline subtotal & & & 10.00 & 10.00 & 6.00 & 9.50 & 7.50 & 7.00 & 7.00 \\
\hline \multicolumn{10}{|l|}{ Hydrogeology } \\
\hline Depth to groundwater & 4.00 & 0.50 & 1.00 & 1.00 & 1.00 & 2.00 & 2.00 & 2.00 & 2.00 \\
\hline $\begin{array}{l}\text { Flow direction conf./unconf. } \\
\text { units }\end{array}$ & 4.00 & 1.00 & 4.00 & 2.00 & 2.00 & 2.00 & 2.00 & 2.00 & 2.00 \\
\hline Simple water table flow & 4.00 & 2.00 & 2.00 & 8.00 & 8.00 & 8.00 & 8.00 & 8.00 & 8.00 \\
\hline Upward hydraulic pressure & 4.00 & 2.50 & 4.00 & 8.00 & 8.00 & 6.00 & 8.00 & 8.00 & 8.00 \\
\hline Groundwater use & 4.00 & 0.50 & 2.00 & 2.00 & 2.00 & 2.00 & 2.00 & 2.00 & 2.00 \\
\hline Continuous confining unit & 4.00 & 2.00 & 8.00 & 8.00 & 8.00 & 8.00 & 8.00 & 8.00 & 8.00 \\
\hline Thickness of confining unit & 4.00 & 1.00 & 4.00 & 4.00 & 4.00 & 4.00 & 4.00 & 4.00 & 4.00 \\
\hline Absence of high conduct zone & 4.00 & 0.50 & 2.00 & 2.00 & 2.00 & 2.00 & 2.00 & 2.00 & 2.00 \\
\hline subtotal & & & 27.00 & 35.00 & 35.00 & 34.00 & 36.00 & 36.00 & 36.00 \\
\hline \multicolumn{10}{|l|}{ Surface Hydrology } \\
\hline Stream proximity & 2.00 & 3.00 & 0.00 & 1.00 & 2.00 & 4.00 & 6.00 & 0.50 & 2.00 \\
\hline Stream quality & 2.00 & 3.00 & 6.00 & 6.00 & 6.00 & 6.00 & 4.00 & 4.00 & 0.00 \\
\hline Stream flow & 2.00 & 3.00 & 0.00 & 5.00 & 5.00 & 5.00 & 6.00 & 6.00 & 2.00 \\
\hline 100-year floodplain & 2.00 & 1.00 & 2.00 & 2.00 & 2.00 & 2.00 & 1.50 & 1.50 & 1.50 \\
\hline subtotal & & & 8.00 & 14.00 & 15.00 & 17.00 & 17.50 & 12.00 & 5.50 \\
\hline \multicolumn{10}{|l|}{ Ecology } \\
\hline Aquatic ccology & 2.00 & 3.50 & 7.00 & 7.00 & 7.00 & 7.00 & 7.00 & 7.00 & 7.00 \\
\hline Terrestrial ecology & 2.00 & 1.00 & 2.00 & 2.00 & 2.00 & 1.50 & 2.00 & 1.00 & 2.00 \\
\hline Set asides & 2.00 & 2.50 & 5.00 & 5.00 & 5.00 & 5.00 & 5.00 & 5.00 & 5.00 \\
\hline Wetlands ecology & 2.00 & 3.00 & 6.00 & 6.00 & 6.00 & 5.50 & 6.00 & 4.00 & 0.00 \\
\hline subtotal & & & 20.00 & 20.00 & 20.00 & 19.00 & 20.00 & 17.00 & 14.00 \\
\hline \multicolumn{10}{|l|}{ Engineering } \\
\hline Borrow availability & 1.00 & 0.50 & 0.30 & 0.30 & 0.30 & 0.30 & 0.30 & 0.30 & 0.30 \\
\hline Drainage layer availability & 1.00 & 0.50 & 0.40 & 0.40 & 0.40 & 0.30 & 0.40 & 0.40 & 0.40 \\
\hline Topsoil & 1.00 & 0.50 & 0.20 & 0.20 & 0.20 & 0.20 & 0.20 & 0.20 & 0.20 \\
\hline Archaeology & 1.00 & 2.00 & 2.00 & 1.50 & 0.50 & 0.75 & 0.10 & 1.00 & 0.00 \\
\hline Proximity to primary roads & 1.00 & 0.50 & 0.50 & 0.50 & 0.50 & 0.50 & 0.50 & 0.50 & 0.50 \\
\hline Proximity to utility corridors & 1.00 & 0.50 & 0.50 & 0.50 & 0.50 & 0.50 & 0.50 & 0.50 & 0.50 \\
\hline Proximity to waste sources & 1.00 & 1.00 & 1.00 & 0.40 & 0.40 & 0.30 & 0.30 & 0.20 & 0.10 \\
\hline Proximity to airport/heliports & 1.00 & 0.50 & 0.30 & 0.50 & 0.50 & 0.50 & 0.50 & 0.50 & 0.50 \\
\hline Security & 1.00 & 0.50 & 0.30 & 0.30 & 0.30 & 0.30 & 0.30 & 0.30 & 0.30 \\
\hline Public Exposure & 1.00 & 1.00 & 0.30 & 0.30 & 0.30 & 0.30 & 0.30 & 0.30 & 0.30 \\
\hline Available area & 1.00 & 2.00 & 1.50 & 0.80 & 1.60 & 2.00 & 1.40 & 1.10 & 1.20 \\
\hline Compatible land use & 1.00 & 0.50 & 0.40 & 0.50 & 0.40 & 0.50 & 0.50 & 0.50 & 0.50 \\
\hline subtotal & & & 7.70 & 6.20 & 5.90 & 6.45 & 5.30 & 5.80 & 4.80 \\
\hline Total & & & 72.70 & 85.20 & 81.90 & 85.95 & 86.30 & 77.80 & 67.30 \\
\hline
\end{tabular}


New Sanitary Landfill

Table 3. Weighted Scores for the Site Selection Critcria

\begin{tabular}{lrrrrrrr} 
Category & $\mathbf{1}$ & \multicolumn{1}{c}{$\mathbf{2}$} & \multicolumn{1}{c}{$\mathbf{3}$} & \multicolumn{1}{c}{} & \multicolumn{1}{c}{$\mathbf{5}$} & \multicolumn{1}{c}{$\mathbf{6}$} & \multicolumn{1}{c}{$\mathbf{7}$} \\
\hline Geology and Soils & 10.00 & 10.00 & 6.00 & 9.50 & 7.50 & 7.00 & 7.00 \\
Hydrogeology & 27.00 & 35.00 & 35.00 & 34.00 & 36.00 & 36.00 & 36.00 \\
Surface Hydrology & 8.00 & 14.00 & 15.00 & 17.00 & $\mathbf{1 7 . 5 0}$ & 12.00 & 5.50 \\
Ecology & 20.00 & 20.00 & 20.00 & 19.00 & $\mathbf{2 0 . 0 0}$ & $\mathbf{1 7 . 0 0}$ & 14.00 \\
Engineering & 7.70 & 6.20 & 5.90 & 6.45 & 5.30 & 5.80 & 4.80 \\
Total & 72.70 & 85.20 & 81.90 & 85.95 & $\mathbf{8 6 . 3 0}$ & $\mathbf{7 7 . 8 0}$ & 67.30
\end{tabular}



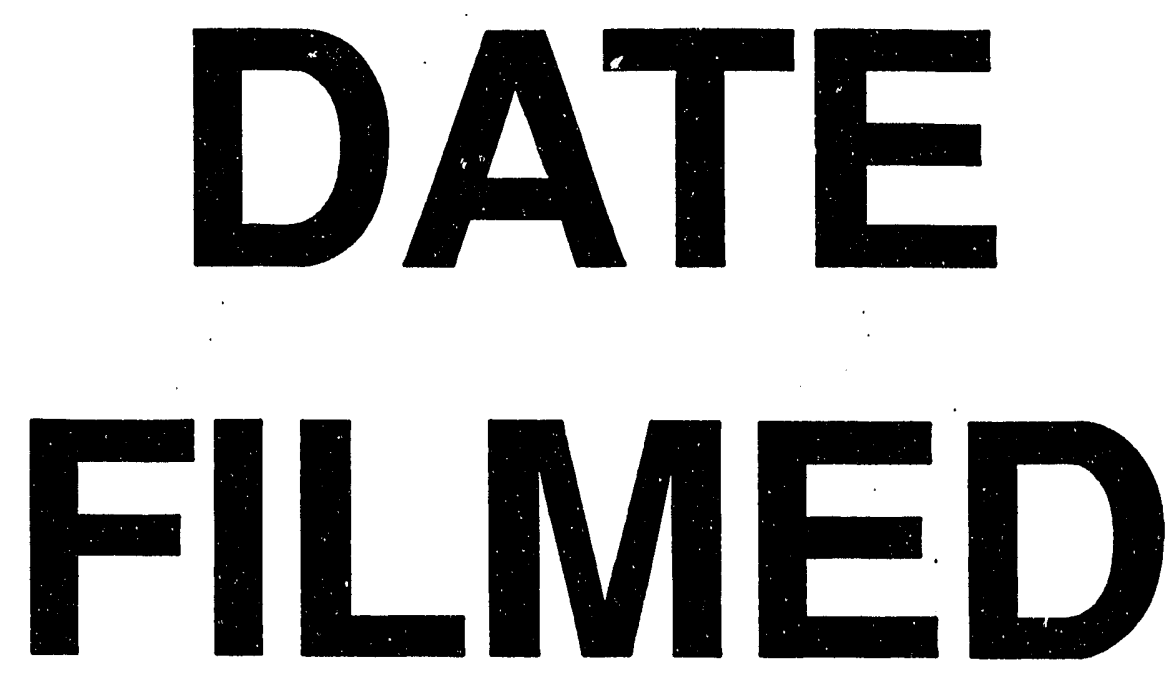

$8 / 17 / 93$
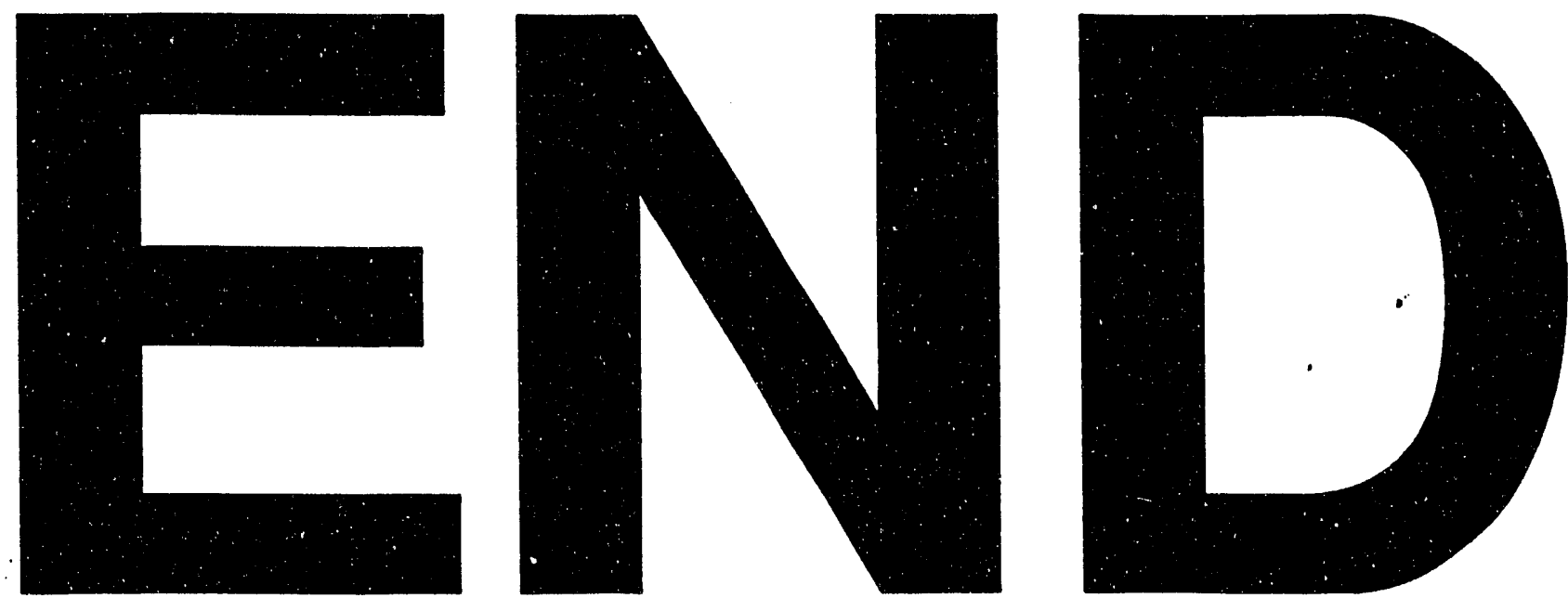
